IQTISHADIA

12,2

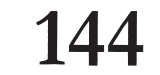

144

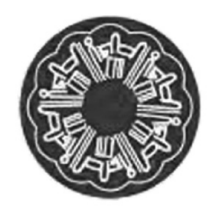

IQTISHADIA

Vol. 12 (2) 2019

PP. 144-172

P-ISSN: $1979-0724$

E-ISSN: $2502-3993$

DOI : 10.21043 iqtishadia.v12i2.5573

\title{
Shariah Screening Methodology: Does It 'Really' Shariah Compliance?
}

\author{
Abdullah Mohammed Ahmed Ayedh \\ abdullah.mohammed@usim.edu.my \\ Universiti Sains Islam Malaysia \\ Amir Shaharuddin \\ amir@usim.edu.my \\ Universiti Sains Islam Malaysia
Muhammad Iqmal Hisham Kamaruddin
m.iqmalhisham@gmail.com
Universiti Sains Islam Malaysia

\begin{abstract}
The purpose of Shariah financial screening indices is to exclude companies with unacceptable levels of conventional debt, liquidity, interest-based investment and/ or impure income. In Islamic perspective, a company must not borrow on the basis of interest rate, nor invest in debt-bearing instruments, as well as not generating income through any other Shariah-impermissible activities. However, such restrictions would screen out the vast majority - if not all - of the stocks that are available on the market, even those listed in Islamic countries. Based on this condition, Shariah scholars tried to come out with a set of Shariah indices to be tested on existing companies in order to classify them as Shariah-compliant companies. However, Shariah screening methodology adopted by major Shariah indices in the world is different from one to another. Thus, the aim of this paper is to explore and critically analyse comparison of Shariah screening methodology amongst major Shariah indices in the world. By applying the reviewing for all related literature and contents of Shariah screening's laws and regulations. It can be stated that several group of Shariah indices can be categorized. Firstly, under qualitative measures (business activities), there are two groups which are: (i) financial activities orientation; and (ii) indic with non-financial activites orientation. Meanwhile, under quantitative measures (financial ratios), another several groups can be categorized based on different adoption in the nominator, denominator and tolerate percentage used. It is hoped that this work would inspire more research on Shariah screening using different research methods and compare between the indices according to segments this research argued. Besides, the policy makers should give more attention to ensure the Shariah screening practices and the enhancement Shariah screening standardizing among the major Shariah indices. Last but not least, investors and stakeholders whom concern of Shariah screening could also benefited of the findings of this study by having better understanding of Shariah screening practices and compare between existed indices.
\end{abstract}

\section{Keywords:}

Shariah screening methodology; Shariah indices; Shariah compliance; Islamic accounting 


\section{INTRODUCTION}

The purpose of the Shariah financial screening indices is to exclude companies with unacceptable levels of conventional debt, liquidity, interest-based investment and/or impure income. Ideally, companies must not borrow on the basis of interest rate, nor invest in debt-bearing instruments, as well as not generating income through any other Shariah-impermissible activities. However, such restrictions would screen out the vast majority - if not all of the stocks that are available on the market, even those listed in Islamic countries (Wilson, 2004). Based on this condition, Shariah scholars tried to come out with a set of Shariah indices to be tested on existing companies in order to classify them as Shariah-compliant companies.

To date, Shariah-compliant companies are being recognized by making a Shariah screening process on securities such as ordinary shares, warrants and transferable subscription rights that are listed on stock exchange market. These Shariah-compliant securities basically are Shariah permissible for investment, based on the company's compliance with Shariah principles in terms of its primary business and investment activities (Mohamad \& Razif, 2013). However, Shariah screening indices used by authorities around the world is different for each other.

One of the major issues resulting from this non-unification of Shariah screening indices is when a company's core business is permissible, but at the same time, it is also involved in some prohibited business (Jamal et al., 2010). In this case, to find ideal companies who are fully Shariah compliant equities are extremely rare (Khatkhatay \& Nisar, 2007). For instance, although a company is fully dealing with Islamic banks for its financial transactions, it still cannot prevent other related parties such as clients and suppliers to also fully dealing with Islamic banks for all their financial transactions. It is almost impossible to find companies which are not dealing with conventional banks and either earn or pay interest (Derigs \& Marzban, 2008).

Another issue from non-unification of Shariah screening criteria is different recognition of Shariah-compliant companies. For instance, a study conducted by Sani and Othman (2013) on 300 Shariah compliant companies in Kuala Lumpur Shariah Index (KLSI) identified that only 39\% of the companies will be entitled for Shariah compliant status if the Shariah screening indices of MSCI (Morgan Stanley Capital International) Islamic Index screening methodology is used. Previously, similar study conducted by Abdul Rahman et al. (2010) on all 565 Shariah-compliant companies listed
Shariah

Screening Methodology

145 
IQTISHADIA

12,2

146

in KLSI also identified that only 198 out of 565 Shariah-compliant companies will be entitled for Shariah compliant status if the Shariah screening indices of Dow Jones Islamic World Index (DJIMI) is used. Last but not least, a study conducted by Zandi et al. (2014) concluded that $68.57 \%$ of the companies approved by KLSI have been accepted under Morgan Stanley Compliance Islamic Index (MSCI) and Financial Times Stock Exchange Shariah Index (FTSE) screening criteria whereas only $40 \%$ of the companies passed DJIM criteria, and $48.57 \%$ passed Standard and Poor's Shariah Index (S\&P) criteria.

In addition, there are also several other similar studies that compares between Shariah screening indices across the world that concluded that KLSI's Shariah screening indices is not as strict as other Shariah screening indices such as DJIMI, MSCI, FTSE and S\&P (Hussin et al., 2015; Kasi \& Muhammad, 2016). This is caused by allowable rate used by KLSI for non-permissible activities which is $5 \%$ and $20 \%$ for designated industry background as compared to only $5 \%$ rate implemented by other authorities around the world. Besides, ratio rate used for quantitative measurement also are vary either $30 \%$ or $33.3 \%$.

Therefore, there is a need to investigate reasons of the different Shariah screening indices used by KLSI to tolerate the non-permissible activities and also the impact of such non-unification of Shariah screening indices used around the world. This is important as Muslim investors are sensitive to seek for Shariah-compliant in investment activities. Besides, inconsistencies in Shariah-compliant status by public listed companies also should be examined in order to identify whether the company undertakes its activities according to Shariah principles or not (Mohd Sanusi et al., 2015).

Therefore, in the next section, this study discusses on the background of Shariah screening methodology including all majority authority bodies who conducting Shariah screening methodology in the world. Further, explanations and discussions between similarities and differences among these majority authority bodies on Shariah indices criteria across global, arguments on the basis of such indices and several recommendation are being made in the following section, which answered the main question of this study whether the existing Shariah indices are 'really' Shariah compliance or not. Finally, the last section provides a summary and concludes the study. 


\section{LITERATURE REVIEW}

\section{Historical Background on Shariah Stock Screening}

Shariah

Screening Methodology

The setting screening criteria was initiated by a team of scholars consist of Muhammad Taqi Usmani (Pakistan), Saleh Tug (Turkey) and Sheikh Mohammad Al Tayyeb Al Najar (Egypt) in 1987 with the objective of finding a solution that would allow Muslim investor to own shares of listed joint stock companies (Mian, 2008; Adam \& Abu Bakar, 2014). Later, fatwa of stocks screening which initiated in the 1990 s as a result of dot-com bubble that attracted many young Muslims to trade in the international stock exchange market by using their families' wealth to benefit from high return. In this period of time, the young committed Muslims inquired about the permissibility of trading in such stocks. However, there is no such guideline to determine the Shariah-compliant companies. In order to recognize Shariah-compliant companies, Sheikh Nizam Yaqoubi proposed general criteria to be applied for identifying Shariah-compliant companies. A group of scholars adopted similar stand and participated in Shariah-committee in different financial institutions (Gamalalden, 2015).

Meanwhile, the first Islamic equity index was introduced in Malaysia by RHB Unit Trust Management Bhd in 1996. Following the establishment of the DJIMI in 1999 and relying on the same principles, the KLSI and FTSE Islamic Index were both launched in the year 1999 (Yildirin \& Ilhan, 2018). In the latest development, Bursa Malaysia, in co-operation with FTSE, introduced a new series of tradable equity indices called FTSE-Bursa Malaysia Emas Shariah Index and FTSE-Bursa Malaysia Hijrah Shariah Index. This development helped to create more opportunities for investors seeking Shariah investments to benchmark their portfolios, and the asset managers to create new products serving the investment community. The Security Commission reported in 2008 that there were over $85 \%$ of total listed Islamic equity companies in Malaysia (Mohd Hussin et al., 2012).

Furthermore, this was the first step in facilitating participation in equity investments that are compatible with the Islamic principles of Shariah. The KLSI provides a benchmark for investors seeking to make investments based on Shariah principles and this helps them to make better informed decisions. The International Islamic Fiqh Academy of the Organization of Islamic Cooperation (IIFA-OIC) allowed participation in joint stock companies whose business activities are completely Shariah compliant. Accordingly, it did not allow involvement in the companies whose business activities are 
IQTISHADIA

12,2

148

either impermissible or a mixture of permissible and impermissible elements (IIFA-OIC, 2000, Resolution \# 63/1/7). The Islamic Fiqh Council (IFC) of the Muslim World League (MWL) also seconded the IIFA-OICs view in its own resolution issued in 1995 (IFC, 2006, Session \#14, Resolution \#4). These Shariah resolutions were perceived as a good step towards establishing the Islamic equity (Habib \& Faruq, 2017).

\section{Shariah Screening Methodologies}

The first criterion of all the Shariah screening methodologies is to exclude companies whose main business activity is impermissible by the Shariah teachings. If the main business activity is Shariah compliant, whereas some secondary activities are not, examination turns to whether or not those secondary activities are within the tolerable benchmarks. One of the ways to examine those secondary activities is by the percentage of income generated from such activities. This component of the criteria is important because it does not only facilitates the measurement of the level of compliance of a company but also indicates how much of the profit needs to be cleansed. The cleansing aspect is also vital for Muslim investors who take a stance that any income generated from a company's Shariah non-compliant activities is impure and thus must be cleansed.

To measure a company's involvement in impermissible secondary activities, its financial operations need to be scrutinised. For this reason, Muslim investors are required to understand the composition of a company's business conduct from two aspects:

(i) The company's general business activities; and

(ii) Its financial operations.

The first aspect is covered under the "Sector and Activity Based Screening", whereas the second aspect is dealt with under the "Quantitative or Financial Screening”. The quantitative or financial screening involves mainly two approaches:

(i) Ensuring that a company's main assets are not predominantly cash or cash-related is the first approach. If a company's main assets are cash based, trading of its shares is tantamount to trading of cash for cash at a discount or premium. This will trigger the issue of riba' (interest) because, in trading currencies or cash, the Shariah rules of currency exchange (bay' al-sarf) should be observed. Similarly, a company's main assets should not be in the form of debts (receivables); otherwise, 
the Shariah rules of debt trading (bay'al-dayn) must be observed to avoid any element of riba'.

(ii) Next approach is ensuring that a company is not involved directly or indirectly in riba'-related activities that exceed the tolerable benchmark specified within the criterion. The riba'-related activities of a company can be in two forms:

a. Investment and/or placement of cash in conventional or interestbased instruments; and

b. Acquiring funds from the capital market or banking sector through interest based facilities.

It should be observed that the first approach considers all types of cash and debt regardless of whether they are Shariah-compliant or not. If the cash or debt reaches or exceeds a certain threshold, the company will be regarded as a cash-based or debt-based company. Therefore, trading its shares at a discount or premium will trigger the issue of riba'. On the contrary, the second approach focuses on the involvement of the companies in riba'related activities such as paying riba' in conventional loans or receiving riba' from investment activities. This approach, therefore, only takes into account the cash placed or invested in Shariah non-compliant instruments. Similarly, only the conventional debt raised through Shariah non-compliant instruments is taken into consideration in the calculation against a certain base.

It is worth noting that some criteria cater for both approaches, whereas some cater for the second approach only. For example, AAOIFI (2015) has a benchmark of maximum $70 \%$ of the total value of all the assets of a company for cash and debt, whether they are Shariah -compliant, Shariah non-compliant or a mixture of both. It means that cash and debt of a company in any form should not exceed $70 \%$ of the total assets. As for the second approach, AAOIFI (2015) suggests that cash placed in interest-based instruments should not exceed $30 \%$ of the market capitalisation of the total equity of a company. And the interest-bearing debt of a company should not exceed $30 \%$ of the market capitalisation of the company. In this way, AAOIFI (2015) covers both approaches in its Shariah standards. In contrast, the Shariah Advisory Council of Securities Commission Malaysia (SAC-SC, 2017) only applies the second approach by having a benchmark of maximum 33\% of total assets for cash placed in conventional instruments, excluding deposits in Islamic accounts. The interest-bearing debt of a company also has a benchmark of maximum $33 \%$ of total assets, excluding Islamic financing facility. With these filters, SAC-SC (2017) opts to observe the second approach only. 
IQTISHADIA

12,2

150

Another point to be noted from the above discussion is that some criteria use total assets of a company as a measuring tool for their filters. For instance, SAC-SC (2017) has adopted total assets to compare interest-earning cash and interest-bearing debt against them. On the contrary, AAOIFI (2015) has suggested market capitalisation of a company to be used for comparison of cash and debt against it. Market capitalisation is the total dollar market value of all outstanding shares of a company. It is calculated by multiplying a company's shares outstanding by the current market price of one share. Investors use this figure to determine a company's size, as opposed to sales or total assets figures.

\section{RESEARCH METHOD}

This study applied a comprehensive library research based for the Shariah screening practices. Thorough and critical survey of the literature related to Shariah screening practices up to January 2019. Various online and offline resources were taken into consideration. The primary source of data collection for the review included research papers and review articles published by reputed publishers such as Springer, Elsevier, Routledge and Taylor \& Francis imprints. Online databases including Scopus and Science Direct were also referred to collect the data on dates. Literature search was conducted using Google Scholar using the following keywords: Shariah screening practices including the nine existed related parties whom provide Shariah indices which include: (i) Accounting and Auditing Organization for Islamic Financial Institutions (AAOIFI); (ii) Dow Jones Islamic Market Indexes (DJIMI); (iii) Kuala Lumpur Shariah Index (KLSI); (iv) Financial Times Stock Exchange Shariah Global Equity Index (FTSE); (v) Standard \& Poor's Shariah Indices (S\&P); (vi) Morgan Stanley Capital International World Islamic Indices (MSCI); (vii) Thompson Reuters Ideal Ratings Islamic Indices; (viii) STOXX Europe Islamic Index; and (ix) ISRA Bloomberg Shariah Stock Screening Indices.

In applying the critical comparison between these Shariah screening indices, two main themes are identified which are: (i) the historic of establishment; and (ii) Shariah screening methodology criteria. The the comparative critical analysis of the Shariah screening methodology is further break into two main categories, consists of business activities (qualitative measure) and financial ratios (quantitative measure). 


\section{Accounting and Auditing Organization for Islamic Financial Institutions (AAOIFI)}

History of Establisment - The AAOIFI was established in 1990 with the aim of preparing accounting, auditing, governance, ethics and other Shariah standards for the Islamic financial institutions. It plays a vital role in harmonizing and standardizing the theoretical basis and practices of Islamic financial institutions at a global level. Its standards have gained acceptance across many jurisdictions on either mandatory or recommended basis, including Saudi Arabia, Bahrain, UAE, Jordan, Lebanon, Qatar, Sudan and Syria (ISRA, 2016). Even in countries where they have not been fully adopted, like Malaysia and Pakistan, they are still heavily relied upon. Its standards also discuss Shariah screening criteria for stocks. Due to the AAOIF's worldwide acceptance of its standards, its Shariah screening criterion is crucially important for many index providers. Many stock exchanges, like Oman, Maldives, Philippines, and institutions, like Azzad, Alfa Bank have adopted AAOIFI's Shariah screening criteria for developing index or investing in stocks. The standard was issued as of 20 May 2004. The standard stated that investing in companies which have allowed purposes but deal with interest and or other impermissible activities is not permitted in principle but can be invested in their stocks as an exception under specific conditions (AAOIFI, 2014).

Shariah Screening Methodology - Under business activity screening, AAOIFI recognizing a Shariah compliant company by ensure that company should not be mainly involved in any impermissible business activities such as activities based on riba or interest/usury (like conventional banks), trading in uncertainty/risk (gharar) (like insurance companies), gambling/games of chance (maysir) (like casinos), manufacturers or traders of impermissible products or services (like liquor, pork and prostitution). Meanwhile, for financial ratio screening, AAOIFI focused on the following financial ratios:

(i) Interest taking deposits less than 30\% to market capitalization of total equity;

(ii) Interest bearing debt less than 30\% to market capitalization of the corporation; and

(iii) Total market value of illiquid assets more than 30\% to market value of the total assets. 
IQTISHADIA

12,2

\section{Dow Jones Islamic Market Indexes (DJIMI)}

History of Establishment - DJIMI are constructed by screening out stocks that are incompatible with Islam's prohibition of interest and certain lines of business (Shamsuddin, 2014). It is the first International Islamic Market Index which was introduced based on Dow Jones Shariah Board Fatwa issued in 1998. The Index was launched in February 1999. DJIMI was the world's first global Shariah-compliant benchmark compliance concerns Muslim investors would otherwise face in constructing Islamic investment portfolios (S\&P Dow Jones Indices LLC, 2018).

Shariah Screening Methodology - The DJIMI Shariah Supervisory Board has adopted a two-stage equity screening process to develop the Dow Jones Islamic market indices (Dow Jones, 2013). At the first stage, a qualitative screening is conducted to exclude sectors whose core business activities are deemed incompatible with the tenets of Islam. In particular, six sectors are identified as forbidden (haram) sectors by the DJIMI Shariah Supervisory Board: (i) alcohol; (ii) pork-related products; (iii) conventional financial services (interest-based banking, conventional insurance, etc.); (iv) entertainment services (hotels, casinos/gambling, cinema, pornography, music, etc.); (v) tobacco; and (vi) weapons and defense. A company is excluded from the DJIMIs if its core business is in any of these sectors.

At the second stage, a quantitative screening is conducted to comply with the prohibition of riba or other impure income. The DJIMI Shariah Supervisory Board uses three financial ratios to screen out firms with high leverage, and interest income and expense. More specifically, each of the following three financial ratios must be less than 33\% (Dow Jones, 2013):

(i) The ratio of total debt to trailing 24-month average market capitalization;

(ii) The ratio of cash and interest-bearing securities to trailing 24-month average market capitalization; and

(iii) The ratio of accounts receivables to trailing 24-month average market capitalization.

\section{Kuala Lumpur Shariah Index (KLSI)}

History of Establishment - The KLSI was launched on 17 April 1999 to cater for increasing demand by local and foreign investors who seek to invest in securities and instruments which are in line with Shariah principles (Ahmad \& Ibrahim, 2002). Investors seeking to make investments based on Islamic laws now have a benchmark for making superior decisions. KLSI was initially 
comprised of 279 companies as of 17 April 1999. However, it has grown to 826 companies as of April 2005, comprising 84\% of the total listed companies on Bursa Malaysia (BNM, 2005). Malaysia is one of the most active countries in Islamic finance. Securities Commission of Malaysia (SC) has created the Shariah Advisory Council (SAC) that has the duty to formulate Shariah screening methodology to assist investors to identify Shariah-compliant securities (Zainudin et al., 2014).

The main objective of the Shariah Advisory Council of Securities Commission is to advise Securities Commission (Resolutions of the Securities Commission Shariah Advisory Council, 2003) on Shariah matters and Shariah guidance for Islamic capital market in Malaysia (Fazilah et al., 2006). It is directly responsible for the regulation and supervision of the activities of the market institutions, including the stock exchanges, clearing house, and monitoring of licenses under the Capital Markets Service Act 2007. SAC will be responsible in determining the status of the securities traded in Bursa Malaysia whether they can be considered as Shariah approved which means that the securities are considered as a halal company for investment or vice versa (Jamal et al., 2010).

Shariah Screening Methodology - The SAC applies both quantitative and qualitative criteria or parameters to select the companies that are Shariah compliant. At the first stage, a qualitative screening is conducted to exclude sectors whose core business activities are deemed incompatible with the tenets of Islam. In particular, companies will be classified as Shariah non-compliant if they are involved in the following core activities by SAC:

(i) Financial services based on riba' (interest);

(ii) Gambling and gaming;

(iii) Manufacture or sale of non-halal products or related product

(iv) Conventional insurance;

(v) Entertainment activities that are non-permissible according to Shariah;

(vi) Manufacture or sale of tobacco-based products or related products;

(vii) Stockbroking or share trading in Shariah non-compliant securities; and

(viii) Other activities deemed non-permissible according to Shariah;

Meanwhile, for the second stage, SAC deals with the issues of mixed contribution (both permissible and non-permissible) in determining the revenue and profit of a company that has passed the qualitative test. SAC uses three financial ratios to screen out firms with high leverage, and interest 
IQTISHADIA

12,2

income and expense. More specifically, each of the following two financial ratios must be less than $33 \%$ :

(i) The ratio of total debt to total asset; and

(ii) The ratio of cash and interest-bearing securities to total asset

In addition, companies with activities comprising both permissible and non-permissible elements, the SAC considers two additional criteria:

(i) The public perception or image of the company must be good; and

(ii) The core activities of the company are important and considered maslahah ('benefit' in general) to the Muslim ummah (nation) and the country (the existing structure of a company enables the majority shareholder of the company to control it.

\section{Financial Times Stock Exchange Shariah Global Equity Index Series (FTSE)}

History of Establishment - Financial Times Stock Exchange Shariah Global Equity Index Series (FTSE) was launched in October 1999. In response to the rising demand for Shariah-compliant investment products, FTSE has developed an enhanced suite of Shariah indexes that use an improved methodology and produce a broader Shariah index solution for Islamic investors. At present, there are about eight main types of indexes under FTSE Shariah Indexes.

Shariah Screening Methodology - Shariah screening from Yasaar will be re-evaluated quarterly in March, June, September and December. Shariah screening process make use of data as at the last day of February, May, August and November and implemented on the working day after the third Friday of March, June, September and December. Both business activity and financial screenings are as follow:

(i) Business Activity Screening - The main areas of business activity screening include conventional finance, alcohol, pork-related products, tobacco, weapons and entertainment. Whilst initial index design tended to adopt an absolute form of exclusion from any of these prohibited activities, recent methodology has tended to employ a five per cent of total revenue-based cutoff using these categories. FTSE screening methodology is based on total sector exclusion, but inclusion of stocks in other sectors where, in aggregate, the proportion of non-compliant revenue is not more than five per cent of the total.

(ii) Financial Screening - Under financial screening, FTSE uses total assets and applies a 33\% cap on the threshold for factors such as total debt relative to total assets, cash and interest-bearing securities over total 
assets. The threshold for the sum of a company's accounts receivable and cash over total assets is set at being less than $50 \%$. Total interest and non-compliant activities income should not exceed $5 \%$ of total revenue.

\section{Standard and Poor's Shariah Indices (S\&P)}

History of Establishment - S\&P Dow Jones Indices introduced S\&P Shariah Indices in 2006 to meet the increasing demand for Shariah-compliant stocks. The indices relied on Rating Intelligence Partners (RI) to provide the Shariah screens and filter the stocks based on these screens (S\&P Dow Jones Indices, 2015).

Shariah Screening Methodology - For Shariah screening process by S\&P, each company's latest financial statement is reviewed to ensure that the company is not involved in any non-Shariah compliant activities, regardless of whether the latest statement is a quarterly, semi-annual or annual statement. If the latest statement is available in all three of these frequencies an annual statement will likely be used, as these are more likely to be audited. Those that are found to be non-compliant are screened out. After removing companies with non-compliant business activities, the remaining companies are examined for compliance with certain financial ratios. Three areas of focus are leverage, cash, and the share of revenues derived from non-compliant activities. All of these are subject to evaluation on an ongoing basis. The summarization of Shariah screening indices by S\&P are as follow:

(i) Business Activity - any involvement (exclude companies which have any involvement in impermissible activities).

(ii) Liquidity Ratios - less than $49 \%$ of account receivable divide by 36 month market average market capital and less than $33 \%$ of cash plus interest bearing securities divide by 36 month average market capital.

(iii) Debt Ratio - less than 33\% of total debt divide by 36 month market average market capital.

\section{Morgan Stanley Capital International World Islamic Indices (MSCI)}

History of Establishment - Establishment a global family of Islamic indices, designed to reflect Shariah investment principles while retaining replicability for international investors. Importantly, the MSCI Global Islamic Indices will incorporate dividend purification rules, resulting in a more relevant benchmark for Shariah portfolios (Shanmugam \& Zahari, 2009). The MSCI 
IQTISHADIA

12,2

Shariah Screening Methodology - Qualitative screenings exclude shares of all such companies engaged in activities strictly prohibited (haram) in Islam. These include companies whose major line of business is dealing with financial transactions involving interest ( $\left({ }^{2} b a^{\prime}\right.$ ), gambling activities (maysr), intoxicants (khamr) such as alcohol or similar drugs that can obscure one's judgment, pork and/or excessive risk taking (gharar) such as insurance and speculative investments. Meanwhile, quantitative screens are used to further screen companies with core activities as permissible (halal) under Shariah but have a portion of revenue from non-permissible activities by set up the following financial ratios with less than 33.33\%:

(i) Total debt to total assets;

(ii) Cash and interest bearing securities to total assets; and

(iii) Account receivables and cash to total assets.

\section{Thompson Reuters Ideal Ratings Islamic Indices}

History of Establishment - IdealRatings has been providing Shariah fund management services for financial institutions since 2006. Its Islamic indices are characterized by quarterly, where research-based Shariah compliance screening performed by IdealRatings accordance to AAOIFI (Accounting and Auditing Organization for Islamic Financial Institutions) adherent. The indices are designed to serve as liquid, broad-based and comprehensive tools for investment professionals and analysts to benchmark and invest in common stock on a local, regional or global basis of Shariah compliant countries. The historical performance for Shariah Indices is available from 1st April 2009. The indices currently cover 20 countries and regions and three sectors, including countries with as few constituents as approximately 10 and as many as approximately several hundred.

Shariah Screening Methodology - IdealRatings has adopted a twostage screening processes to develop its Islamic indices. At the first stage, 
a qualitative screening is conducted to exclude sectors whose core business activities are deemed incompatible with the tenets of Islam. In particular, several sectors are identified as forbidden (haram) sectors by IdealRatings, which are: (i) non-halal food production; (ii) tobacco; (iii) alcohol; (iv) gambling; (v) advertisement; (vi) hotels; (vii) non-Islamic banks, financial institutions and insurance companies; (viii) entertainment and music production; (ix) trading of gold and silver, as well as weaponry; and (x) arms manufacturers. Meanwhile, at the second stage, a quantitative screening is conducted by using the following three financial ratios:

(i) Theratio of total debt to trailing 12-month average market capitalization is less than $30 \%$;

(ii) The ratio of cash, deposits and interest bearing investment dividend to total assets is less than 30\%; and

(iii) The ratio of cash, deposits and receivables to total assets is less than $67 \%$.

\section{The STOXX Europe Islamic Index}

History of Establishment - The STOXX Islamic indices are designed to provide broad equity market exposure in compliance with Shariah principles for Europe and the Eurozone. The index components are selected by means of an advanced proprietary screening technique. The screening process is monitored by the STOXX European Islamic Index Shariah Supervisory Board. The STOXX Islamic 50 indices are blue-chip indices designed to provide large-cap equity market exposure in compliance with Shariah principles for the respect region. The Shariah Supervisory Board of STOXX Europe Islamic Index has issued its fatwa (opinion) defining stocks screening principles and guidelines on 21 February 2011.

Shariah Screening Methodology - The stocks 'screening process consists of business activities and financial ratio. Companies which their primary activities include non-halal (impermissible) food production (e.g. pork, alcohol and tobacco), conventional financial and insurance companies, gambling, weapon and arms manufacturing, entertainment and trading of gold and silver are excluded (STOXX, 2011b). The remaining companies are filtered in accordance to the following financial screening (STOXX, 2011b):

(i) Non-Shariah compliant debt to total assets (or total market capitalization, whichever is greater) ratio cannot exceed $33 \%$.

(ii) Interest bearing assets to total assets (or total market capitalization, whichever is greater) ratio cannot exceed $33 \%$. 
IQTISHADIA

12,2

However, the unique element in the ISRA-Bloomberg methodology is that the platform highlights the degree of Shariah non-compliant activities of companies. It does not merely list them as Shariah-compliant companies. Company A, for instance, may be listed as a Shariah-compliant company with $4.7 \%$ of its income coming from Shariah noncompliant activities. This extra feature will bring mainly two benefits to investors:

(i) Better decisions can be made on whether to buy, hold or sell shares of Shariah compliant companies which are near the $5 \%$ threshold.

(ii) The amount of dividend cleansing can easily be done based on the disclosed percentage of income derived from Shariah non-compliant activities.

Operationally, activities of companies are categorized in different colors to identify their Shariah-compliant status. The different colors shown are the result of a sophisticated consideration process. The companies which are completely Shariah non-compliant are highlighted in red; the companies which are completely Shariah-compliant are shown in white; and the companies which have mixed activities are shown in blue. The companies in red and the companies which have exceeded the tolerable benchmark in blue are excluded from the Shariah-compliant universe. In addition, the system can compute how much income (the exact amount) is from impermissible activities based on the revenue segment, which may be coded either red or blue. This system helps investors in precisely knowing which type of sectors and activities the companies are operating and involved in. The blue-coding basically indicates the following:

(i) It is not known if the company's activities in a sector are Shariah compliant or not, for example, the category of "Food and Beverages". In this regard, company's activities in the sector are regarded as Shariah non-compliant unless declared otherwise by the company. The declaration must fulfil certain criteria including its transparency 
in Bloomberg's portal. For instance, a company may declare through a supplementary document that it is only involved in halal food and beverages. Based on this declaration, the "blue status" may be changed to "white".

(ii) The sector and activity may involve mixed activities. Part of those activities may be regarded as Shariah non-compliant. "Hotel" is an example where its activities include accommodation (Shariahcompliant) and non-halal food and beverages and liquor bar (Shariah non-compliant). In this regard, the sector and activity will be regarded as Shariah non-compliant except if declared otherwise by the company. Similar to the previous case, in this case as well, the company has to follow the same procedure to be included in the Shariah-compliant list.

After the sector screening, the companies are subject to financial screening. There are two financial ratios that need to be met. These are cashbased ratio and debt-based ratio. More specifically, each of the following three financial ratios must be less than $33 \%$ :

(i) The ratio of total debt to trailing 24-month average market capitalization; and

(ii) The ratio of cash place in conventional account to assets.

\section{RESULT AND DISCUSSION}

Stock screening is a process of determining whether a stock or security is Shariah compliant or not. It consists of a variety of Shariah principles that form the criteria which should be used to decide whether the stock or security is Shariah compliant or not. The main objective of screening the stock is to ensure the stock or security that one purchases or invests in does not contain any forbidden elements that make it Shariah non-compliant. For Muslims, it is a severe sin to consume something that is unlawful or prohibited. Basically, all major Shariah indices are using two stages screening which are explained as follows in Figure 1: 


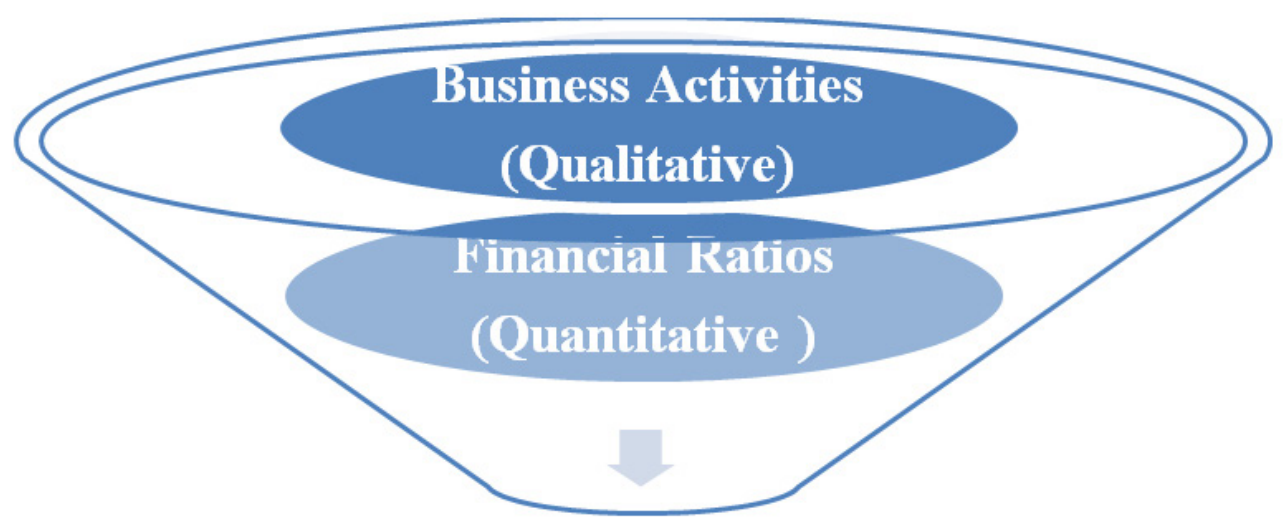

\section{Shariah Compliant \\ Companies}

\section{Shariah Indices Screening Methodologies}

Based on previous discussion on major Shariah indices around the world, the following Table 1 summarized the Shariah screening methodologies which focusing on business activities (qualitative measurement).

Table 1

Summary of Shariah Screening Methodologies by Business Activities

Indices

Accounting and Auditing Organization for Islamic Financial Institutions (AAOIFI)

Dow Jones Islamic Market Indexes (DJIMI)

\section{Percentage \\ Level}

Exclude companies with impermissible core businesses including activities based on riba' (like conventional banks), trading in uncertainty/risk (gharar) (like insurance companies), gambling/ games of chance (maysir) (like casinos), manufacturers or traders of impermissible products or services (like liquor, pork, prostitution, etc.)

Excludes companies involved in:

- Alcohol;

- Tobacco;

- Pork-related products;

- Conventional financial services (banking, insurance etc.);

- Weapon and defense; and

- Entertainment (hotels, casinos/gambling, cinema). 


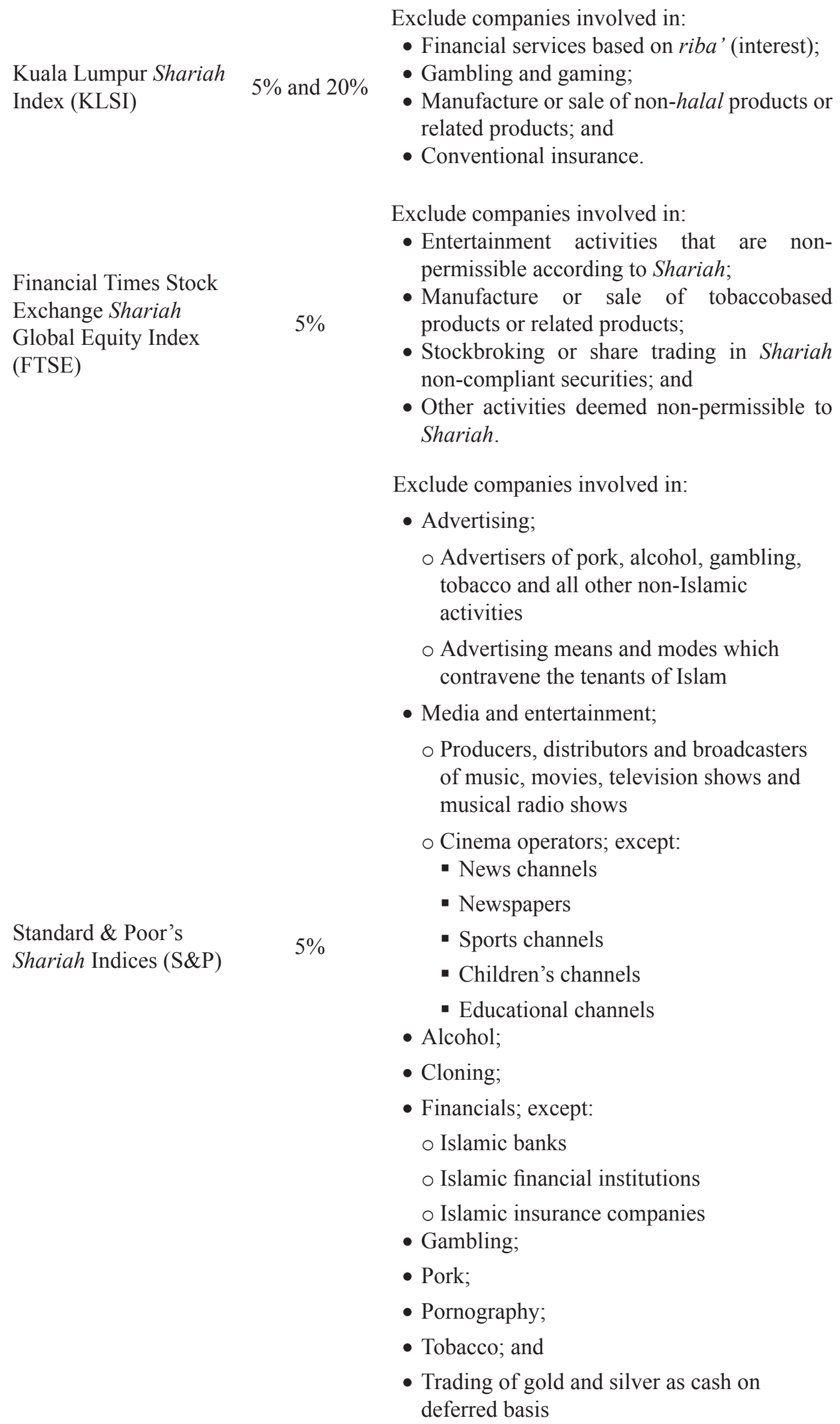

Exclude companies involved in:

Kuala Lumpur Shariah Index (KLSI)

$5 \%$ and $20 \%$

- Financial services based on riba' (interest);

- Gambling and gaming;

- Manufacture or sale of non-halal products or related products; and

- Conventional insurance.

Exclude companies involved in:

- Entertainment activities that are nonpermissible according to Shariah;

Financial Times Stock

Exchange Shariah

Global Equity Index

$5 \%$

(FTSE)

Standard \& Poor's

Shariah Indices (S\&P)

- Manufacture or sale of tobaccobased products or related products;

- Stockbroking or share trading in Shariah non-compliant securities; and

- Other activities deemed non-permissible to Shariah.

Exclude companies involved in:

- Advertising;

○ Advertisers of pork, alcohol, gambling, tobacco and all other non-Islamic activities

o Advertising means and modes which contravene the tenants of Islam

- Media and entertainment;

o Producers, distributors and broadcasters of music, movies, television shows and musical radio shows

o Cinema operators; except:

- News channels

- Newspapers

- Sports channels

- Children's channels

- Educational channels

- Alcohol;

- Cloning;

- Financials; except:

o Islamic banks

o Islamic financial institutions

o Islamic insurance companies

- Gambling;

- Pork;

- Pornography;

- Tobacco; and

- Trading of gold and silver as cash on deferred basis

Shariah

Screening

Methodology 
IQTISHADIA

12,2

162
Thompson Reuters Ideal Ratings Islamic

Indices

\section{The STOXX Europe Islamic Index}

Morgan Stanley

Capital International World Islamic Indices (MSCI)
Exclude companies involved in:

- Alcohol;

- Tobacco;

- Pork related product;

- Conventional financial services;

$5 \%$ - Defense/Weapons;

- Gambling/Casino;

- Music;

- Hotels;

- Cinema; and

- Adult entertainment

Non-compliant income sources include the following:

- Adult entertainment;

- Alcohol;

- Cinema and broadcasting;

- Conventional insurance;

5\% - Conventional financial services;

- Defense;

- Gambling;

- Hotels and music;

- Operating and non-operating interest income; and

- Pork and tobacco

Exclude companies involved in:

- Non-halal food production;

- Tobacco;

- Alcohol;

- Gambling;

- Advertisement;

- Hotels;

- Non-Islamic banks, financial institutions and insurance companies;

- Entertainment and music production;

- Trading of gold and silver, as well as weaponry; and

- Arms manufacturers.

ISRA Bloomberg

Shariah Stock

Adapting similar Shariah screening on business activities criteria by AAOIFI

Table 1 above highlights that the Shariah screening methodology used by the major Shariah indices in the world on qualitative measurement which is based on business and financial activities. Shariah screening methodology by business activities is measurement companies with impermissible core businesses including activities based on riba' (like conventional banks), trading in uncertainty/risk (gharar) (like insurance companies), gambling/ 
games of chance (maysir) (like casinos), manufacturers or traders of impermissible products or services (like liquor, pork, prostitution, etc.).

In addition, impermissible including trading of gold and silver as cash on deferred basis. Gold and is the well-known natural element and precious metal. It is, in gold is the well-known natural element and precious metal. It is, in principle, a fungible item (measured by weight) and a ribawi commodity, principle, a fungible item (measured by weight) and a ribawi commodity, and is subject to the Shariah rulings for currency exchange (al-sarf). It is very important to note that the Prophet Muhammad (PBUH) pointedly forbade forward buying and selling in all of the aforementioned cases.

The major Shariah indices in the world has excludes companies with these activities. Thus, according to all major Shariah indices in the world such as DJIMI, KLSI, FTSE, S\&P, MCSI, Thompson Reuters Ideal Ratings Islamic Indices and The STOXX Europe Islamic Index having similar agreement on the allowable percentage as $5 \%$ on Shariah non-compliant incomes from total business revenues. The $5 \%$ is assess the level of mixed contributions from activities that are clearly prohibited such as riba' based activities, gambling, liquor and pork; interest income from conventional accounts and instruments and tobacco-related activities. However, based on data observation found that the KLSI have the additional measurement which is $20 \%$. Since KLSI has implemented the two-tier approach on Shariah screening methodology. The $20 \%$ which is to assess the level of contributions of mixed rentals from Shariah non-compliant activities and to assess the level of mixed contributions from activities that are generally permissible according to Shariah and have an element of maslahah (public interest), but there are other elements that may affect the Shariah status of these activities e.g. hotel and resort operations. Thus, this is an effort to harmonise the standards to global expectation and to spur capital inflows, especially from Middle East investors.

From the above discussion, we can categorize the existed Shariah indices as follows, firstly, indices with financial activities orientation (i.e. AAOIFI; KLSI; ISRA). Secondly, indic with non-financial activites orientation (DJIMI; FTSE; S\&P; MSCI; Thompson Reuters Ideal Ratings Islamic; STOXX Europe Islamic). For the financial activities indices, the criteria relatively same. However, the indices with non-financial activites orientation, there is a variance in terms of the number of critteria and details. Based in the number of criteria and details, the S\&P is more conservatism and detailed indic. Besides that, KLSI were setup 5\% and 20\% percentage level on the business activities.

Impermissible to the financial services based on riba' (interest), gambling and gaming, manufacture or sale of non-halal products or related
Shariah

Screening Methodology

163 


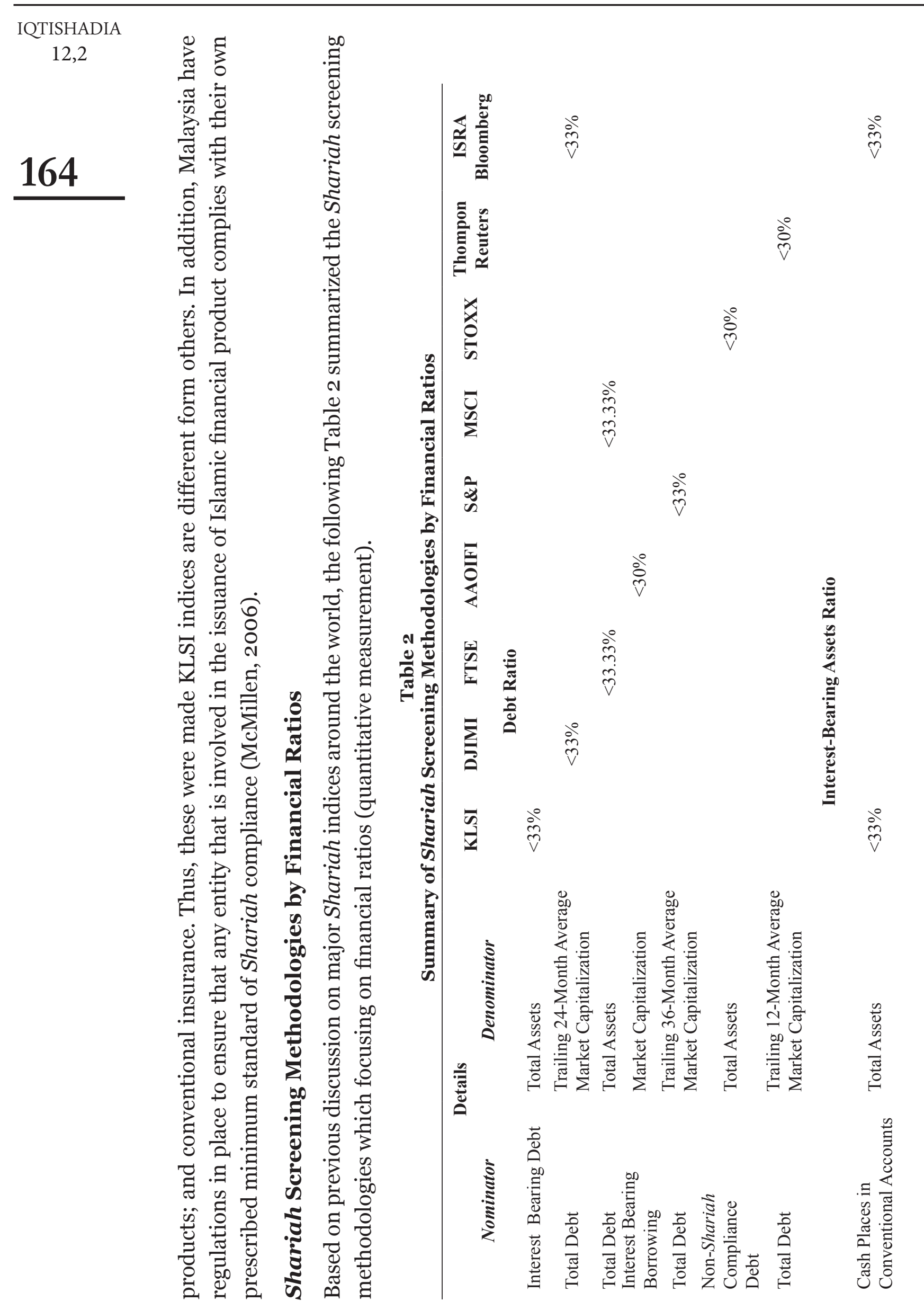


Shariah

Screening

Methodology

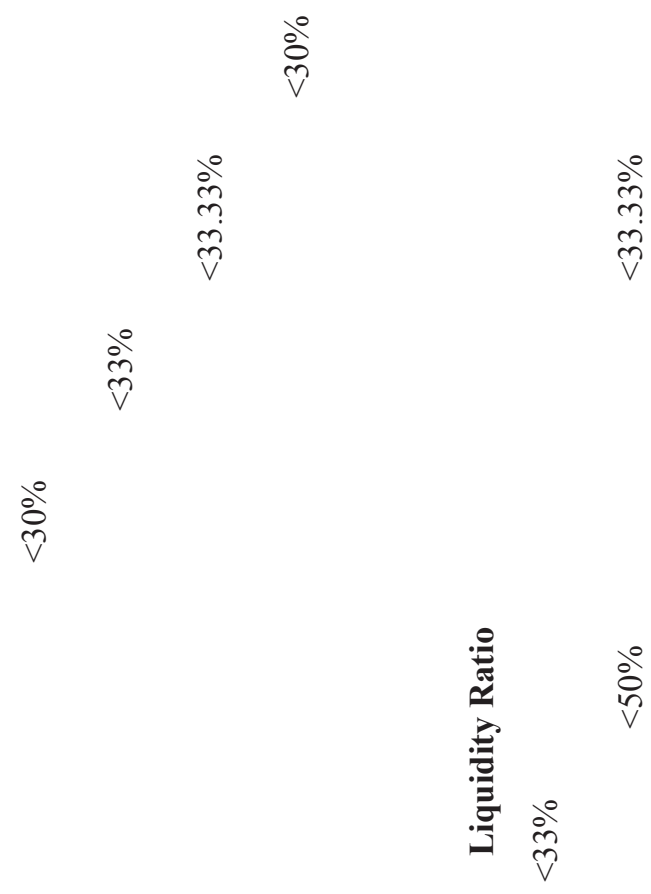

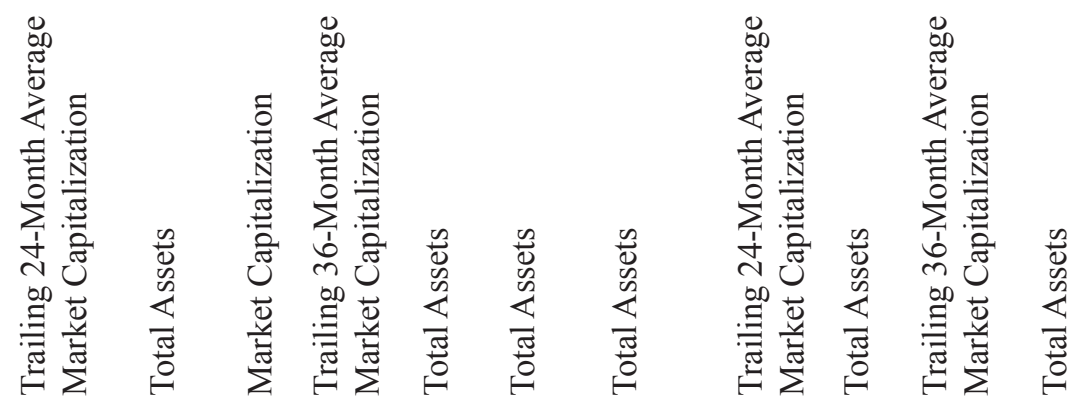

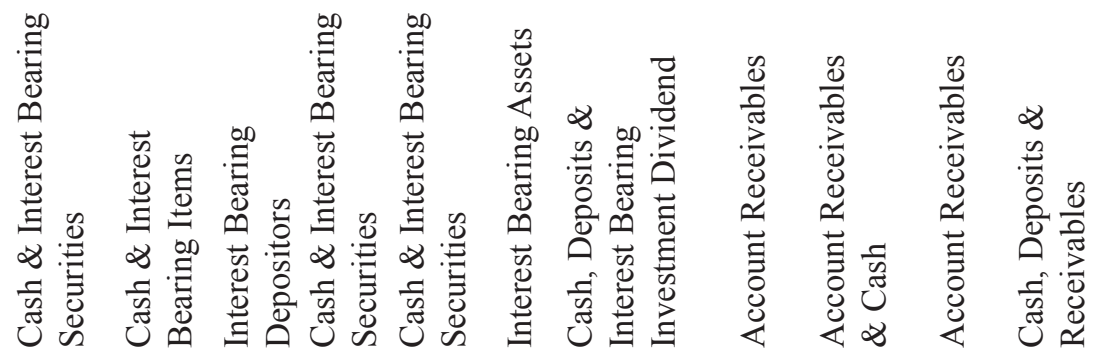


IQTISHADIA

12,2

166

Table 2 above highlights that the Shariah screening methodology used by the major Shariah indices in the world on quantitative measurement which is based on financial ratios. The quantitative or financial screening involves mainly two approaches which is to ensuring that a company's main assets are not predominantly cash or cash-related is the first approach. Next approach is ensuring that a company is not involved directly or indirectly in riba'-related activities that exceed the tolerable benchmark specified within the criterion. A comprehensive comparison of the nine users' quantitative screening methods is compiled in Table 2. Each user has a list of ratios for each criterion and it plays an important role in the quantitative screening method. This compilation of all ratios and criteria used provide systematic information for comparison within the Shariah context. The classification of quantitative criteria set by the users is summarized into several financial ratios' indicators are used including debt, interest bearing assets and liquidity. However, nominator and denominator used by each major Shariah indices in calculating these ratios are different.

Debt and interest-bearing debt (IBD) items fall under the category of debt screen and since Islamic finance follows the principle of sharing of risks and profits, borrowings and repayments of interest and principle is not Shariah compliant. It is observed that the level of debt criterion is screened by all except Shariah compliance because it does not consider debt a major issue in their quantitative screen. There seems to be a consensus among the users to apply the benchmark of one third as the parameter of tolerance level stipulated by understandings from the Hadith. In summary, it is generally acceptable to have some debt in Shariah compliant business Meanwhile for liquidity screen, It is claimed that market capital provides the real worth of the company but since it is driven by market sentiments, the volatility of price movement affects the threshold value and create inconsistency problem where Shariah compliant status of the listed companies tend to change over time. Some users therefore argue that the use of average market capital is more suitable in order to smooth out any uncertainty in market price movements. This may have led to DJIMI, AAOIFI Shariah Standard No.21, S\&P Shariah Indices, Thompon Reuters Idealratings Islamic Indices and ISRA Bloomberg Shariah Stock Screening Indices are preference to use either total debt or market capitalization to avoid the seasonality effect in the Shariah complaint status. Meanwhile, KLSI, FTSE, MCSI and STOXX use total assets. 
The Shariah boards classified five sets of ratios under the liquidity screen: debt plus liquid funds, accounts receivable, accounts receivable plus cash, accounts receivable and cash plus other debt, and illiquid assets. While DJIMI and S\&P quantify current asset solely to measure the level of liquidity. Meanwhile, FTSE, MSCI and Thompson Reuters quantify market capitalization solely to measure the level of liquidity. The thresholds for liquidity screen ratios diverse greatly between $33 \%$ and $67 \%$ and this show different Shariah jurisdictions referral in setting the threshold level in liquidity screenings. Moreover, KLSI, AAOIFI, STOXX and ISRA are not measure the level of liquidity.

Under the category of interest-bearing assets ratio screen, eight sets of ratios are classified: (i) cash places in conventional accounts; (ii) total assets; (iii) cash and interest-bearing securities; (iv) cash and interest-bearing items; (v) interest bearing depositors; (vi) market capitalization; (vii) interest bearing assets and cash deposits; and (viii) interest-bearing investment dividend. Interest income is screened by five users and the general consensus is $33 \%$ being the maximum threshold limit. A standard benchmark of one third is used for cash plus interest bearing securities. The difference between the users is again on the divisor, while cash plus interest bearing securities (IBS) use either total assets or average market capital as the divisor, interest income ratio is divided by total revenue or income. This may be due to the existence of cash and IBS in the balance sheet instead of interest income from the income statement. The nominator and denominator are matched depending on their extraction from the respective financial statements.

In general, based on these quantitative ratios, it can be divided into three main ratios which are: (i) debt ratio; (ii) interest-bearing assets ratio; and (iii) liquidity ratio. Basically, major Shariah indices applying these three ratios differently from one to another especially in term of the nominator and denominator with different tolerate percentage. For instance, from denominator aspects, there are two main groups which one who were adopting total asset as denominator and another group were adopting market capitalization. Under market capitalization's group, it still can be differentiate either solely on the current market capitalization value, trailing 12-months average market capitalization, trailing 24-months average market capitalization and trailing 36-months average market capitalization.

Meanwhile, from percentage aspect, qualitative indics can be categorized into either $30 \%$ or $33.33 \%$. The percentage is basically derived from using 
IQTISHADIA

12,2

168

legal maxim 'Shariah ruling on primary assets, which come from the following Hadith narrated by Saad Abi Waqas:

"I became seriously ill at Mecca and the Prophet came to visit me. I said, "O Allah's Messenger! I shall leave behind me a good fortune, but my heir is my only daughter; shall I bequeath two third of my property to be spent in charity and leave one third (for my heir)?" He said, "No." I said, "Shall I bequeath half and leave half?" He said, "No." I said, "Shall I bequeath one third and leave two thirds?" He said, "One third, and one third is much." (Hadith No.5659, Imam Bukhari).

Based on the Hadith, it is notified that the exact percentage mentioned is one third or equivalent to 33.33\%. However, as in Table 2, several major indics such as AAOIFI, STOXX and Thompson Reuters are using 30\% instead of one third or $33.33 \%$ mentioned in the Hadith. In addition, for liquidity ratio, the permissible percentage adopted were different from $30 \%$ or $33.33 \%$, which are not exceeding $50 \%$ by FTSE, $49 \%$ by S\&P and $67 \%$ by Thompson Reuters. The differences on permissible percentage for liquidity ratio is basically depends on Shariah ruling on primary asset as mentioned in the following two Hadiths:

"When a person buys a palm-grove after pollination, then the fruit is for the seller, unless the buyer stipulates this too" (Hadith No.2204, Imam Bukhari).

"When a person buys a slave, who has wealth, then the wealth is for the seller, unless the buyer stipulates this too" (Hadith No.2379, Imam Bukhari).

The differences in the quantitative ratios can be caused by different objectives among the Shariah screeners, whether country-specific, regulationoriented or globally business-oriented (Khatkhatay and Nisar, 2007; Abdul Rahman et al., 2010; Ho, 2015). Therefore, inconsistencies in the method of classification used by different groups will make some stocks that are deemed permissible by one group may be non-permissible by other groups (Derigs \& Marzsban, 2008). There are two main reasons of dissimilarities among Muslim scholars in terms of Islamic investment screening criteria, which are:

(i). Modern finance and investment is a new phenomenon and hence, the current practice is based on ijtihad of contemporary scholars who have different Shariah opinions.

(ii).There is no higher Islamic authority that is responsible for religious rulings to be followed by all Muslims. 


\section{CONCLUSION}

This paper explore and critically analyse comparison of Shariah screening methodology amongst major Shariah indices in the world. The purpose of this paper is to focus on the Shariah compliant screening methods that are practiced by prominent Shariah indices in the world, in terms of qualitative and quantitative screening. This research uses comparative analysis to recognize the similarities and differences of methods among nine Shariah indices in the world. Some of these indices are more specific in their listing of Shariah impermissible business and activities while some are more lenient. All the users practices a two-tier method of screening: qualitative and quantitative. Under quantitative screen, the range of allowable ratios among non-permissible criteria and the measurement formula differ between boards. Some countries have their respective Shariah screening boards and they set different standards depending on the roles and objectives they play in the industry. Although there are possibilities that other exchanges or countries may provide their own screening method, most fund managers, banks and industry players do not have such screening facilities and thus have to rely on market intelligence providers that screen global assets at macro level.

Shariah screening of stocks is the backbone of Islamic capital market. An efficient and practical Shariah screening methodology is the key for having a robust criterion for stocks, because based on this criterion the fate of stocks, in terms of being Shariah compliant or non-compliant, is decided. The more the criterion of Shariah screening is theoretically strong and practically viable, the more the investors, companies, regulators and other players of the Islamic capital market have confidence in the market.

Yet the current study placed the ground for further empirical studies and donated significantly to the area of Shariah screening practices. This study is still subject to a number of limitations. Firstly, as stated above this paper is based on critical analysis review of the literature and contents of Shariah screening's laws and regulations. Future research might integrate the current study findings into an empirical research.

The current work's findings implications could be summarized as follows. First, hopefully these findings provide better and comprehensive picture and understanding of the Shariah screening practices existed. It hopes that this work would inspire more research on Shariah screening using different research methods and compare between the indices according to segments this research argued. Second, the policy makers might give more attention to ensure the Shariah screening practices and the enhancement Shariah screening standardizing among the major Shariah indices. Thirdly,
Shariah

Screening Methodology

169 
IQTISHADIA

12,2

170

by critically analyze the Shariah screening methodologies and evaluate them based on the leniency level, which assist in the evaluating and identifying the best practice of Shariah screening. Finally, investors and stakeholders whom concern of Shariah screening could also benefited of the findings of this study by having better understanding of Shariah screening practices and compare between existed indices.

\section{References}

AAOIFI. (2015). Shari'ah Standards. Manama: Accounting and Auditing Organization for Islamic Financial Institutions.

AAOIFI. (2014). Shariah Standards, Manamah - Bahrain, Accounting and Auditing Organization for Islamic Financial Institutions.

Ahmad, Z., \& Ibrahim, H. (2002). A study of the performance of the KLSE Syari'ah index. Malaysian Management Journal, 6(1): 25-34.

Abdul Rahman, A., Yahya, M. A, \& Mohd Nasir, M. H. (2010). Islamic Norms for Stock Screening: A Comparison between the Kuala Lumpur Stock Exchange Islamic Index and the Dow Jones Islamic Market Index. International Journal of Islamic and Middle Eastern Finance and Management, 3(3): 228-240.

Adam, N. L., \& Bakar, N. A. (2014). Shariah Screening Process in Malaysia. Procedia-Social and Behavioral Sciences, 121, 113-123.

Bank Negara Malaysia. (2005). KLSI and KLCI daily closing prices. Retrieved on June 2005, from http://www.bnm.gov.my/index.php?ch=128. $\mathrm{pg}=140 /$.

Derigs, U., \& Marzban S. (2008). Review and Analysis of Current Shariahcompliant Equity Screening Practices. International Journal of Islamic and Middle Eastern Finance and Management, 1(4): 28530.

Dow Jones. (2013). Dow Jones Islamic Market Indices: Overview. Retrieved from http://www.djindexes.com/islamicmarket/ (Accessed on 16 December 2013).

Fazilah, M. A. S. (edited). (2006), The Malaysian Financial System: An Overview, University Malaya Press, Kuala Lumpur.

Gamaleldin, F. M. (2015). Shariah-Compliant Stocks Screening and Purification. Master Dissertation, University of Liverpool, United Kingdom. 
Habib, F., \& Faruq, A. A. U. (2017). Revisiting the AAOIFI Shariah Standards' Stock Screening Criteria. International Journal of Business \& Society, 18(1): 151-166.

Hashim, A. M., Habib, F., Isaacs, Z., \& Gadhoum, M. A. (2017). ISRA Bloomberg Shari'ah Stock Screening and Income Cleansing Methodologies: A Conceptual Paper. ISRA International Journal of Islamic Finance, 9(1): 27-42.

Ho, C. S. (2015). International Comparison of Shari'ah Compliance Screening Standards. International Journal of Islamic and Middle Eastern Finance and Management, 8(2): 222-245.

Hussin, A. H., Hussin, N. H. \& Abdul Razak, D. (2015). Shariah Stock Screening Methodology:A Comparison Between Shariah Advisory Board of Securities Commission Malaysia andInternational Index Providers. In Hashim, R. and Abdul Majeed, A.B. (Eds.), Proceedings of the Colloquium on Administrative Science and Technology (pp.191202). Singapore: Springer Link.

ISRA. (2016). Islamic Financial System: Principles and Operations (2nd Eds.). Kuala Lumpur, Malaysia: International Shar'ah Research Academy for Islamic Finance.

Jamal, J., Hambali, N., \& Mohd Ali, H. (2010). Islamic capital market and Shari'ah screening in Malaysia. International Research Symposium in Service Management (pp.1-16).

Kasi, U., \& Muhammad, J. (2016). Strict and Uniform Shariah Screening Methodologies in Selected Asian Countries in Comparison with the United States. Asian Journal of Finance \& Accounting, 8(1), 38-76.

Khatkhatay, M. H., \& Nisar, S. (2006). Shariah-Compliant Equity Investments: An Assessment of Current Screening Norms. Islamic Economic Studies, 15(1): 47-76.

McMillen, M. J. T. (2006). Islamic capital markets: developments and issues. Capital Markets Law Journal, 1(2): 136-72.

MSCI. (2013). MSCI Barra Launches Global Family of Islamic Indices: Dividend Purification and Broad Country Coverage: Retrieved from https://www.morganstanley.com/press-releases/msci-barralaunches-global-family-of-islamic-indices_5275. (Accessed on May 5, 2019).

Mian, K. M. A. (2008). Shariah Screening and Islamic Equities Indices. Islamic Finance News, 5(17).

Mohd Hussin, M.Y., Muhammad, F., Abu, M.F., \& Awang, S.A. (2012). Macroeconomic Variables and Malaysian Islamic Stock Market: A 
IQTISHADIA

12,2

172

Time Series Analysis. Journal of Business Studies Quarterly. 3(4); $1-13$.

Mohamad, S., \& Razif, N. F. M. (2013). Shariah Compliant Securities, Sukuk and Islamic REITs in Malaysia. In Ahmad, W. M. W. (Eds.), Islamic Economics, Banking and Finance: Concept and Critical Issues, Pearson, 121-139.

Mohd-Sanusi, Z., Ismail, R., Hudayati, A., \& Harjito, D. (2015). Screening Process of Shariah-Compliant Companies: The Relevance of Financial Risk Management. International Journal of Economics \& Management, 9(1): 177-195.

SAC-SC. (2017). Frequently-Asked Questions on Revised Shariah Screening Methodology, available at: www.sc.com.my/frequently-askedquestions-on-revised-shariah-screening-methodology/ (accessed 22 March 2017).

Sani, N. A., \& Othman, R. (2013). Revision of Shariah Screening Methodology: The Status of Shariah-Compliant Companies in Malaysia. Proceedings of the 3 rd International Conference on Management (3rd ICM 2013), Malaysia, 51-63.

S\&P Dow Jones Indices LLC. (2018). Shariah (Dow Jones Islamic Market). Retrieved from https://us.spindices.com/index-family/shariah/dowjones-islamic-market (Accessed on Mac 5, 2019).

Shamsuddin, A. (2014). Are Dow Jones Islamic equity indices exposed to interest rate risk? Economic Modelling. 39, 273-281.

Shanmugam, B., \& Zahari, Z. R. (2009). A Premier on Islamic Finance.

Yildirim, R., \& Ilhan, B. (2018). Shari'ah Screening Methodology - New Shari'ah Compliant Approach. Journal of Islamic Economics, Banking and Finance, 14(1): 168-191.

Zandi, G., Abdul Razak, D., \& Hussin, N. (2014). Stock Market Screening: An Analogical Study on Conventional and Shariah-Compliant Stock Markets. Asian Social Science, 1O(22). 